\title{
On-farm trees are a safety net for the poorest households rather than a major contributor to food security in Rwanda
}

\author{
Alain Ndoli ${ }^{1,2,3}$ - Athanase Mukuralinda ${ }^{4}$ - Antonius G. T. Schut ${ }^{1} \cdot$ Miyuki liyama $^{5}$ - Jean Damascene Ndayambaje ${ }^{4}$. \\ Jeremias G. Mowo ${ }^{6} \cdot$ Ken E. Giller ${ }^{1}$. Frédéric Baudron ${ }^{3}$
}

Received: 4 January 2020 / Accepted: 25 December 2020 / Published online: 29 January 2021

(C) The Author(s) 2021

\begin{abstract}
The world is challenged to meet the food demand of a growing population, especially in developing countries. Given the ambitious plans to scale up agroforestry in Africa, an improved understanding of the effect of agroforestry practices on the already challenged food security of rural households is crucial. The present study was undertaken to assess how on-farm trees impacted food security in addition to other household income sources in Rwanda. In each of the six agroecologies of Rwanda, a stratified sampling procedure was used where two administrative cells (4th formal administrative level) were selected in which households were randomly selected for interviews. A survey including 399 farmers was conducted and farmers were grouped in three types of agroforestry practice (i) low practitioners (LAP) represented by the first tertile, (ii) medium practitioners (MAP) represented by the second tertile and (iii) high practitioners (HAP) represented by the third tertile of households in terms of tree number. Asset values, household income sources, crop production, farm size, crop yield, and food security (food energy needs) were quantified among the types of agroforestry practice. A larger proportion of HAP households had access to adequate quantity and diversity of food when compared with MAP and LAP households. Food security probability was higher for households with more resources, including land, trees and livestock, coinciding with an increased crop and livestock income. We found no difference in asset endowment among types of agroforestry practices, while farmers in agroecologies with smaller farms ( 0.42 ha to $0.66 \mathrm{ha}$ ) had more on-farm trees (212 to 358 trees per household) than farms in agroecologies with larger farms ( 0.96 ha to 1.23 ha) which had 49 to 129 trees per household, probably due to differences in biophysical conditions. A positive association between tree density and food security was found in two out of six agroecologies. The proportion of income that came from tree products was high (> 20\%) for a small fraction of farmers (12\%), with the more food insecure households relying more on income from tree products than households with better food security status. Thus, tree income can be percieved as a "safety net" for the poorest households.
\end{abstract}

Keywords Agro-ecological zones $\cdot$ Agroforestry $\cdot$ Food self-sufficiency $\cdot$ Household income

Alain Ndoli

alain.ndoli@iucn.org; ndolialain@gmail.com

1 Plant Production Systems, Wageningen University, PO Box 430, 6700 AK Wageningen, The Netherlands

2 International Union for Conservation of Nature (IUCN)- Eastern and Southern Africa Region, PO Box 6935, Kigali, Rwanda

3 International Maize and Wheat Improvement Centre (CIMMYT)Southern Africa Regional Office, Mt Pleasant, Peg Mazowe Road, PO Box MP163, Harare, Zimbabwe

4 World Agroforestry Centre (ICRAF), Nairobi 30677-00100, Kenya

5 Japan International Research Center for Agricultural Sciences (JIRCAS), 1-1 Owashi, Tsukuba, Ibaraki 305-8686, Japan

6 Association for Landuse, Environmental care, Research and Technology transfer (ALERT), P.O. Box 2682, Arusha, Tanzania

\section{Introduction}

The double challenge faced by the world is to meet the food demand of the growing population, and to do so in ways that are environmentally and socially sustainable (Von Braun 2007). Sub-Saharan Africa remains amongst the most food insecure regions in the world, with $22.8 \%$ of the population showing prevalence of undernourishment (FAO et al. 2019). In this region, population pressure has led to shorter fallow periods or continuous cropping, even on hillslopes causing erosion and leading to reduced soil organic matter content and nutrient mining without replenishment (Stoorvogel and Smaling 1990). Agroforestry, a low-input technology, is said to contribute to the enhancement of food production while 
ensuring sustainability in sub-Saharan Africa (Garrity 2012). Agroforestry was defined by ICRAF (2013) as "the inclusion of trees in farming systems and their management in rural landscapes to enhance productivity, profitability, diversity and ecosystem sustainability". Agroforestry could also be defined as a dynamic, ecologically based, natural resource management system that, through the integration of trees on farm and rangeland, diversifies and sustains smallholder production for increased social, economic and environmental benefits (Leakey 1996). Agroforestry is now receiving increasing attention as a sustainable land-management option because of its ecological, economic, and social attributes.

Agriculture is the primary source of livelihood for $85 \%$ of the rural population in the developing world (Dixon et al. 2001). In countries such as Rwanda, smallholder farming is commonly practiced on farms smaller than one hectare (NISR 2010) and is highly vulnerable to weather related shocks, such as drought and irregular rains (Hjelm et al. 2015). Rwanda is characterized by one of the most severe nutrient depletion rates in Africa and low soil organic carbon content (Stoorvogel and Smaling 1990; Drechsel et al. 2001). The country is dominated by sloping agricultural land (up to $55 \%$ ) with $50 \%$ showing signs of erosion. Producing enough food on nutrient deficient land for the rapidly growing population is challenging and buying imported food would be too expensive for most of the population who currently live on less than one dollar (USD) per day. Despite the economic recovery of Rwanda since 1994, household food insecurity and malnutrition remain a challenge in the country. In 2012, as many as 460,000 households (21\%) were food insecure (NISR 2012). This number increased to 473,847 households (20\%) in 2015 (Hjelm et al. 2015). Though the percentage of food insecure households decreased slightly, the absolute number of food insecure households increased due to population growth.

In light of recurring food shortages, projected climate change, and rising prices of fossil fuel-based agricultural inputs, interest in agroforestry has recently increased as a costeffective means to enhance food security, while at the same time contributing to climate change adaptation and mitigation (Mbow et al. 2014). Rwanda government officials, NGOs, and extension specialists perceive smallholder agroforestry as a suitable strategy for smallholder farmers (Stainback et al. 2012). Consequently, Rwanda has pledged to restore 2 million hectares of land (almost $100 \%$ of arable land) by the year 2030 mainly through agroforestry (http://www. bonnchallenge.org/content/rwanda). Food security is one of the main drivers in agroforestry adoption in Africa (Brown et al. 2013). For instance, Coulibaly et al. (2017) found that agroforestry increased food security in Malawi. Kristjanson et al. (2012) found a strong positive relationship between food security and the adoption of agroforestry farming in Ethiopia, Kenya, Uganda, and the United Republic of Tanzania, though it was not determined whether adoption had induced more food security or vice-versa.

While agroforestry may improve food security through increased income from tree products (Garrity Dennis et al. 2010) and enhanced crop production (Coulibaly et al. 2017), it may also reduce it by lowering crop yields (Ndoli et al. 2017) under trees due to competition for resources shared between trees and crops (Kho 2000). Despite the potential positive impact of agroforestry on food security, its contribution to food security in relation to other sources of household income is still unknown. There is a need for an improved understanding of the role of trees on farm income and the food security status of farmers to better understand and anticipate the likely impacts of current efforts to upscale agroforestry on rural households in Rwanda. The present study seeks to understand how the trees grown and managed on-farm affect farm income and food security of households in the six agroecological zones of Rwanda. The specific objectives were: (i) to determine whether agroforestry practices lead to diversification and increase of income and value of assets; and (ii) to evaluate food security for households that differ in the number of trees on their farms.

\section{Materials and methods}

\subsection{Data collection}

The study was conducted in the six agroecologies of Rwanda as defined by Djimde (1988). However, the Eastern Savannah lowland, as defined in 1988 was subdivided into two systems, namely Eastern Savannah and Eastern Plateau (Table 1). This is because the Eastern Savannah became heterogeneous in terms of socioeconomic and biophysical characteristics in the last two decades. The Eastern Savannah of 1988 was a less populated parkland with the protected Akagera national park covering half of it. Eastern Savannah used to be occupied by a National Park but in late 1990s, its biggest share was settled by former refugees and they started farming activities which completely changed the land cover/land use. What used to be savannah woodland was then converted into farmland and rangeland by clearing the forest. A short description of the characteristics of the land use systems is presented in Table 1. The administrative structure of Rwanda is organized into provinces, districts, sectors, cells and villages. In each agroecology, one representative district was selected, based on biophysical and socio-economic factors. A stratified sampling was used to ensure that each subgroup of households received good representation within the sample. Two 
Table 1 Characteristics of the six agroecologies [source: Djimde 1988, if not otherwise specified with a superscript number]

\begin{tabular}{|c|c|c|c|c|c|c|}
\hline Characteristics & Eastern Savannah & Eastern Plateau & Buberuka highland & $\begin{array}{l}\text { Volcanic } \\
\text { highland }\end{array}$ & Central Plateau & Congo Nile Crest \\
\hline Elevation (m) & $1200-1400$ & $1200-1500$ & $1900-2000$ & $2200-2400$ & $1100-1700$ & $1900-2500$ \\
\hline Rainfall (mm year ${ }^{-1}$ ) & $800-1000$ & $800-1000$ & $1200-1300$ & $1300-1500$ & $1000-1500$ & $1300-2000$ \\
\hline Temperature $\left({ }^{\circ} \mathrm{C}\right)$ & $>21$ & $20-21$ & $15-18$ & $<15$ & $18-20$ & $<15-18$ \\
\hline $\begin{array}{l}\text { Proportion of very } \\
\text { fertile soil }(\%)^{\mathrm{a}}\end{array}$ & 48 & 54 & 37 & 66 & 41 & 6 \\
\hline $\begin{array}{l}\text { Food insecure } \\
\text { households in the } \\
\text { study cells }(\%)^{\mathrm{b}}\end{array}$ & $3-7$ & $8-15$ & $15-28$ & $8-28$ & $15-28$ & $33-43$ \\
\hline $\begin{array}{l}\text { Dominant } \\
\text { agroforestry } \\
\text { practices }^{\mathrm{b}}\end{array}$ & $\begin{array}{c}\text { Trees on farm } \\
\text { boundaries }\end{array}$ & $\begin{array}{l}\text { Scattered trees on } \\
\text { farm, trees on } \\
\text { contour }\end{array}$ & $\begin{array}{c}\text { Woodlot, contour } \\
\text { hedgerows and } \\
\text { home gardens }\end{array}$ & $\begin{array}{l}\text { Woodlot, } \\
\text { contour } \\
\text { hedge- } \\
\text { rows }\end{array}$ & Scattered trees on farm & $\begin{array}{l}\text { Woodlot, contour } \\
\text { hedgerows, } \\
\text { Scattered trees } \\
\text { on farm }\end{array}$ \\
\hline $\begin{array}{l}\text { Tree Species } \\
\text { dominant in the } \\
\text { surveyed zones }^{\mathrm{a}}\end{array}$ & $\begin{array}{l}\text { Grevillea, } \\
\text { Eucalyptus, } \\
\text { Avocado, Senna, } \\
\text { Mango, Papaya }\end{array}$ & $\begin{array}{l}\text { Grevillea, Senna, } \\
\text { Eucalyptus, } \\
\text { Avocado, Mango, } \\
\text { Calliandra }\end{array}$ & $\begin{array}{l}\text { Alnus, Eucalyptus, } \\
\text { Avocado, } \\
\text { Erythrina, Ficus, } \\
\text { Grevillea }\end{array}$ & $\begin{array}{l}\text { Alnus, } \\
\text { Eucalypt- } \\
\text { us, } \\
\text { Erythrina }\end{array}$ & $\begin{array}{l}\text { Avocado, Eucalyptus, } \\
\text { Calliandra, Grevillea, } \\
\text { Citrus, Orange, } \\
\text { Mango }\end{array}$ & $\begin{array}{l}\text { Eucalyptus, } \\
\text { Grevillea, } \\
\text { Avocado, } \\
\text { Calliandra, Ficus }\end{array}$ \\
\hline Livelihood $^{\mathrm{b}}$ & Agro pastoral & $\begin{array}{l}\text { Banana, cassava and } \\
\text { mixed agriculture }\end{array}$ & $\begin{array}{l}\text { Beans, wheat, Irish } \\
\text { potato and } \\
\text { vegetables }\end{array}$ & Irish potato & Cassava and coffee & $\begin{array}{l}\text { Subsistence food } \\
\text { crop farming and } \\
\text { labour in tea } \\
\text { estates }\end{array}$ \\
\hline
\end{tabular}

${ }^{\mathrm{a}}$ Mukuralinda et al. (2016)

${ }^{\mathrm{b}}$ NISR (2012)

cells, representing the 4th formal administrative level in Rwanda from each district were selected based on contrasting outcomes with respect to the incorporation of trees on farm and they were used for assessment of the contribution of trees on household food security.

A household survey was conducted between November and December 2014 in each selected cell with about 20-60 randomly selected households (Mukuralinda et al. 2016; Iiyama et al. 2018a; b). From a list of all households, a sample was randomly selected and visited for interviews. A total of 465 households were interviewed in the 12 selected cells but this study uses 399 households which had full information. A structured questionnaire was administered to respondents' household heads or their representatives during the survey. Questions related to tree species, number of trees (defined in this study as woody perennial plants with a minimum height of $2 \mathrm{~m}$ excluding recently planted seedlings), products and income from trees. The questionnaire also captured the household socioeconomic characteristics, crop production, and income from crops, from livestock and from off farm activities. Farm and field areas were computed from field boundaries as recorded with a Global Navigation Satellite System (GNSS) receiver (Garmin) and with this on-farm crop productivity (i.e., crop yields converted to gigajoules (GJ) energy per ha) was determined. To this end, for each field the farmer reported harvested amounts of grain, tuber or fresh product were converted to dry mass estimates, using standard values for dry matter content from Feedipedia and USDA web databases (http://www.feedipedia.org/;: https://ndb.nal.usda.gov/ $\mathrm{ndb} / \mathrm{search}$ ), and divided by the measured field area. Household asset values were determined. While measuring farm area, surveyors could quickly count trees to confirm the number of trees reported by the farmer. Assets were grouped into four categories: (i) domestic (i.e., sofa set, refrigerator, wood stove, kerosene stove, gas/LPG stove, granary and domestic water tank), (ii) communication (i.e., radio, mobile phone, television), (iii) transport (i.e., bicycle, motorbike, car/truck and ox cart), and (iv) farming assets (i.e., water tank for irrigation, hoes, machetes, ox-plough, wheelbarrow, grain-mill, water pumps, milk can, shovel, spades, axe, and sprayer). Food security status throughout the year was evaluated in the questionnaire where farmers were asked to assign each month of the year to one of the following categories:

(1) not enough food for all members of the household: lack of access to food quantity and quality that normally satisfies each member of the household throughout each month of the year, 
(2) enough food but not enough diversity: access to food quantity that normally satisfies each member of the household but not in the desired quality throughout each month of the year, or

(3) enough food and enough diversity: access to food quantity and quality that normally satisfies each member of the household throughout each month of the year.

Therefore, the required quantity and diversity of food in this study is the perception of farmers interviewed.

Key informants (farmer groups, extension workers, researchers and policy makers) were interviewed to validate the survey data as a part of a more comprehensive study for the project 'Taking to scale tree-based systems that enhance food security, improved resilience to climate change, and sequester carbon in Rwanda' (Mukuralinda et al. 2016).

\subsection{Data analysis}

Assets as well as income were compared between types of agroforestry practice and between agroecologies using a Kruskal Wallis test while proportions of farmers in different food security categories were compared with Chi-square tests. (Welham et al. 2004).

Three relative types of number of trees on farm were constructed using tertiles in each agroecology; (i) low agroforestry practitioners (LAP) defined as the first tertile of the households in terms of tree number, (ii) medium agroforestry practitioners (MAP) defined as the second tertile of the households in term of tree numbers and (iii) high agroforestry practitioners (HAP) defined as the third tertile of the households in terms of tree numbers. Tukey's test in the PredictMeans $\mathrm{R}$ package (Welham et al. 2004) was used for pairwise comparisons of different household assets between LAP, MAP and HAP for each agroecology (Fig. 1).

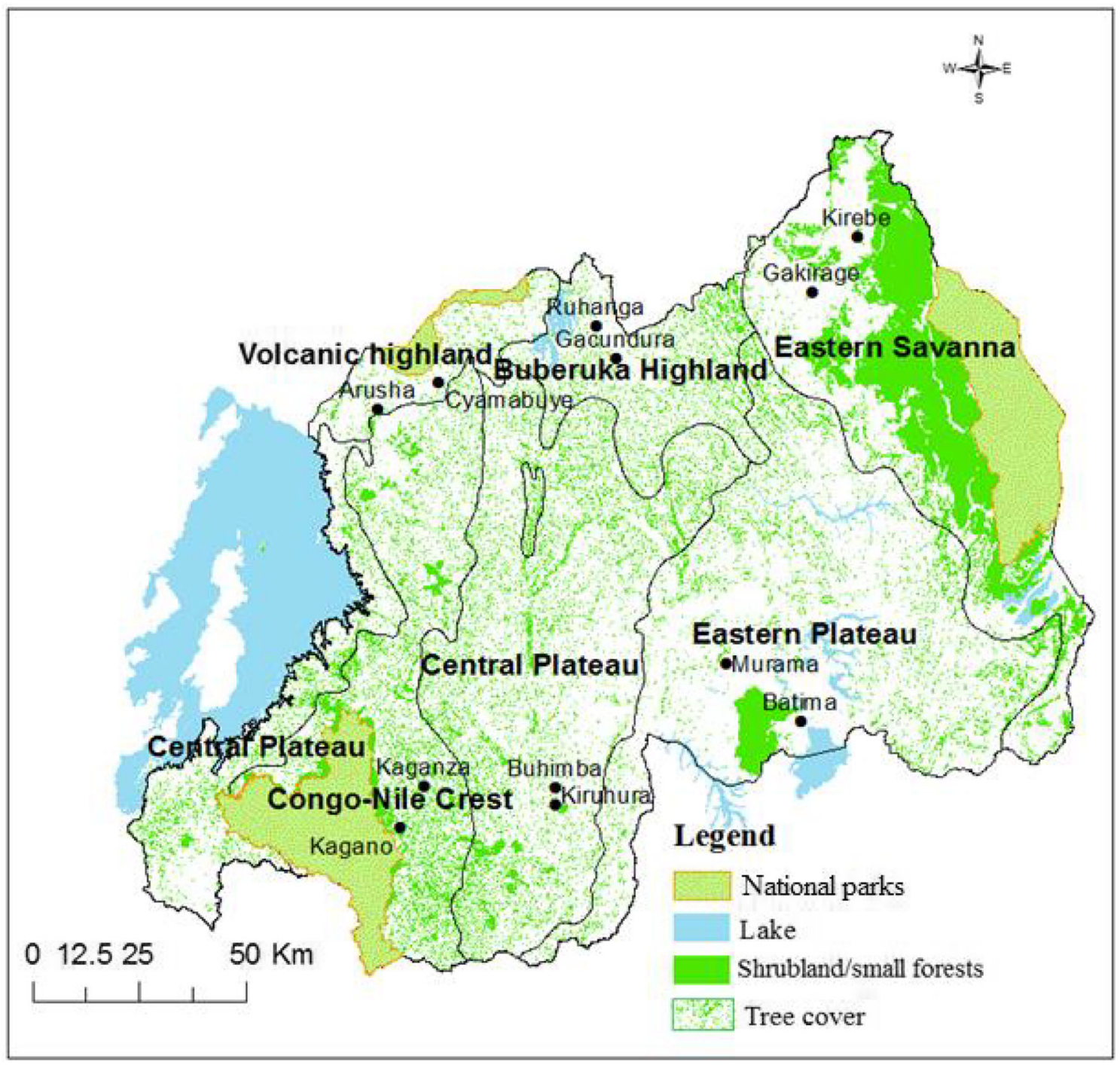

Fig. 1 Map of 2012 tree cover in Rwanda displaying the six agrecologies and the study sites that were selected for this study 
While 465 households were interviewed, 66 farmers had reported inaccurate farm sizes or did not have either land or trees and were thus removed from the analysis. Food security for the remaining 399 households was ranked as ' 1 ' if they did not have enough food and not enough variety (carbohydrates, proteins, and fats), ' 2 ' if they had enough food but not enough variety and ' 3 ' if they had enough food and enough variety. Generalized linear models were used to assess the source of variability in food security. Model 1 aimed at testing the effect of tree number when controlling for structural variables (e.g., farm area). Model 2 aimed at testing the effect of tree income when controlling for other functional variables (e.g., crop productivity, offfarm income). Both Model 1 and Model 2 were run for the whole dataset. In the analysis, the scores 2 and 3 for the response variable 'food security status' were combined and considered as food secure households (coded as 1) to signify households having at least access to food quantity that normally satisfies each member of the household throughout the month. These were compared to food insecure households (coded as 0 ) which are those without access to food quantity that satisfies each member of the household throughout the month. A logistic regression model was then used. The Analysis of Variance (ANOVA) was conducted to compare effects and differences were evaluated for their significance with a Chi-square test. Models were constructed as follows:
(Model 1) $Y_{i j}=\alpha+\beta F S T C A E_{i}+\gamma M O_{j}+\gamma C I+\delta L I+\rho O I+\sigma C P+R$ (Model 2) $Y_{i}=\alpha+\beta T I+\gamma C I+\delta L I+\mu A E_{i}+\varepsilon O I+\epsilon C P+\theta A E_{i} T I$ $+\vartheta A E_{i} C I+\pi A E_{i} L I+\rho A E_{i} O I+\sigma A E_{i} C P+R$

where $Y_{i j k l m}$ and $Y_{\text {mnopqr }}$ represents the binomial values of food security status (with the value 1 for food secure and 0 for food insecure), $T C$ is the number of trees on-farm, $M O_{j}$ is the $j^{\text {th }}$ month of the year, FS is the farm size in hectares, $A E i$ is the $\mathrm{i}^{\text {th }}$ agroecology, TI is the tree income, CI is the crop income, $L I$ is the livestock income, $O I$ is the off-farm income, $C P$ is the value of crop production in calories, and $R$ is the residual, and where $\alpha, \beta, \gamma, \delta, \mu, \tau, \varepsilon, \epsilon, \theta, \vartheta, \pi, \rho$ and $\sigma$ represent effects values. We used $\mathrm{R}$ software for all statistical analyses (R Development Core Team 2014).

\section{Results}

Households were grouped in types of agroforestry practice using tertiles, see Table 2. The mean number of trees grown by households was higher in the Congo Nile agroecology, followed by Buberuka Highlands, Eastern Plateau, Volcanic Highlands, and Central Plateau while the Eastern Savannah had the smallest number of trees. The number of on-farm trees in the Congo Nile agroecology was seven-fold larger than in the Eastern Savannah agroecology (least covered with trees), and 1.7 times larger than in the Buberuka Highland which
Table 2 Characteristics of the selected households in the six agroecologies of Rwanda. Standard errors are given after the signs ' \pm ' for mean number of trees and total land size per household. $P$ values from Kruskal-Wallis tests are given to compare levels of agroforestry practice (LAP: low practitioners, MAP: medium practitioners, HAP: high practitioners)

\begin{tabular}{|c|c|c|c|c|c|}
\hline Land use & LAP & MAP & HAP & Mean & $\mathrm{P}$ \\
\hline \multicolumn{6}{|c|}{ No. of households } \\
\hline Buberuka H & 14 & 14 & 14 & & - \\
\hline Central Plat & 29 & 29 & 29 & & - \\
\hline Congo Nile & 20 & 20 & 20 & & - \\
\hline Eastern Plat & 23 & 23 & 23 & & - \\
\hline Eastern Sav & 18 & 18 & 18 & & - \\
\hline Volcanic H & 29 & 29 & 29 & & - \\
\hline \multicolumn{6}{|c|}{ Mean no. of trees } \\
\hline Buberuka H & $29 \pm 4.4$ & $95 \pm 8.3$ & $508 \pm 94.3$ & $212 \pm 12.6$ & $<0.001$ \\
\hline Central Plat & $2 \pm 0.2$ & $10 \pm 0.9$ & $195 \pm 14.48$ & $69 \pm 5.3$ & $<0.001$ \\
\hline Congo Nile & $3 \pm 0.5$ & $99 \pm 15$ & $964 \pm 184.3$ & $358 \pm 23.3$ & $<0.001$ \\
\hline Eastern Plat & $7 \pm 0.8$ & $26 \pm 2$ & $355 \pm 139.8$ & $129 \pm 14.29$ & $<0.001$ \\
\hline Eastern Sav & $2 \pm 0.2$ & $7 \pm 0.6$ & $136 \pm 57.7$ & $49 \pm 5.9$ & $<0.001$ \\
\hline Volcanic H & $14 \pm 1.5$ & $41 \pm 1.8$ & $309 \pm 81.3$ & $121 \pm 8.7$ & $<0.001$ \\
\hline \multicolumn{6}{|c|}{ Total land size (ha) } \\
\hline Buberuka $\mathrm{H}$ & $0.64 \pm 0.2$ & $0.63 \pm 0.19$ & $1.06 \pm 0.3$ & $0.76 \pm 0.04$ & $<0.001$ \\
\hline Central Plat & $0.32 \pm 0.08$ & $0.38 \pm 0.1$ & $0.77 \pm 0.21$ & $0.49 \pm 0.02$ & $<0.001$ \\
\hline Congo Nile & $0.49 \pm 0.17$ & $0.29 \pm 0.07$ & $0.48 \pm 0.14$ & $0.42 \pm 0.04$ & $<0.001$ \\
\hline Eastern Plat & $0.75 \pm 0.20$ & $0.74 \pm 0.14$ & $1.39 \pm 0.26$ & $0.96 \pm 0.07$ & $<0.001$ \\
\hline Eastern Sav & $0.59 \pm 0.13$ & $1.37 \pm 0.49$ & $1.71 \pm 0.51$ & $1.23 \pm 0.07$ & $<0.001$ \\
\hline Volcanic H & $0.73 \pm 0.25$ & $0.45 \pm 0.06$ & $0.56 \pm 0.12$ & $0.58 \pm 0.03$ & 0.003 \\
\hline
\end{tabular}


ranks second in high number of trees. Total farm area per household was generally larger in agroecologies with fewer trees per household. Farm size was larger in the Eastern Savannah $(1.23 \pm 0.07 \mathrm{ha})$ and Eastern Plateau $(0.96 \pm$ $0.07 \mathrm{ha})$, followed by Buberuka Highlands $(0.76 \pm 0.04 \mathrm{ha})$, Central Plateau ( $0.49 \pm 0.02$ ha), Volcanic Highland (0.58 \pm $0.03 \mathrm{ha})$ and lastly the Congo Nile agroecology $(0.42 \pm$ 0.04 ha). In Central Plateau, Eastern Plateau, and Eastern Savannah, farm size of HAP was larger than the rest of the types while farm size was not different among agroforestry practice levels in the highlands agroecologies (Buberuka Highlands, Congo Nile, and Volcanic Highlands).

Income from trees was generally higher for HAP than MAP and LAP but its contribution to total household income was small compared with other sources of income. Tree income for HAP were four times higher than for MAP and 21 times higher than for LAP. Tree income and crop income were significantly higher in HAP than the rest of the agroforestry practice types in Congo Nile and Eastern Plateau. In addition, crop income was higher for HAP than for MAP and LAP in Eastern Savannah while livestock income was only higher for
HAP in Congo Nile when compared to MAP and LAP (Table 3). Off-farm income was not higher in HAP than in MAP and LAP. Figure 2 shows the contribution of four farm income sources to the total household income. Around 35\% of farm households earn income from trees, about $25 \%$ of households earn income from crops and livestock, while about $40 \%$ of households earn income from off-farm activities (Fig. 2).

Asset ownership tended to be similar among the different types of agroforestry practices, except in the Congo Nile agroecology where communication assets were significantly higher in HAP as compared to the other types. On average, HAP had assets worth USD 289, 73, 32, and 50 for domestic, communication, transport and farm assets respectively. MAP had assets worth USD 303, 61, 38, and 29 for domestic, communication, transport, and farm assets respectively. The corresponding asset value in the LAP type were USD 302, 57, 52, and 20 (Table 4). Assets did not significantly vary among farmers and were hence not included among factors that directly distinguish wealth in the study sites. Livestock value was not considered as a household asset but income from livestock was captured and used in the analysis.
Table 3 Agroforestry practice levels (LAP: low practitioners, MAP: medium practitioners, HAP: high practitioners) as a function of income sources (USD/ year). Means followed by the same letter in the same agroecology and the same income source do not differ significantly at $\alpha=0.05$. Standard errors are given after the signs ' \pm '

\begin{tabular}{|c|c|c|c|c|}
\hline Agroecology & Income source (USD) & LAP & MAP & HAP \\
\hline Buberuka & Tree & $7 \pm 1^{\mathrm{b}}$ & $6 \pm 1^{\mathrm{b}}$ & $44 \pm 5^{\mathrm{a}}$ \\
\hline \multirow[t]{3}{*}{ Highland } & Crop & $155 \pm 18^{\mathrm{b}}$ & $139 \pm 14^{\mathrm{b}}$ & $251 \pm 26^{\mathrm{a}}$ \\
\hline & Livestock & $10 \pm 3^{\mathrm{b}}$ & $22 \pm 5^{\mathrm{b}}$ & $43 \pm 6^{\mathrm{a}}$ \\
\hline & Off farm & $90 \pm 10^{\mathrm{b}}$ & $445 \pm 96^{\mathrm{a}}$ & $119 \pm 17^{\mathrm{b}}$ \\
\hline \multirow[t]{4}{*}{ Central Plateau } & Tree & $5 \pm 0.1^{\mathrm{b}}$ & $26 \pm 4^{\mathrm{b}}$ & $195 \pm 20^{\mathrm{a}}$ \\
\hline & Crop & $213 \pm 24^{\mathrm{b}}$ & $320 \pm 34^{\mathrm{ab}}$ & $345 \pm 42^{\mathrm{a}}$ \\
\hline & Livestock & $39 \pm 6^{\mathrm{b}}$ & $25 \pm 4^{\mathrm{b}}$ & $262 \pm 53^{\mathrm{a}}$ \\
\hline & Off farm & $216 \pm 38^{\mathrm{a}}$ & $144 \pm 17^{\mathrm{a}}$ & $135 \pm 24^{\mathrm{a}}$ \\
\hline \multirow[t]{4}{*}{ Congo Nile } & Tree & $14 \pm 2^{\mathrm{c}}$ & $77 \pm 18^{\mathrm{b}}$ & $158 \pm 14^{\mathrm{a}}$ \\
\hline & Crop & $78 \pm 11^{\mathrm{b}}$ & $180 \pm 22^{\mathrm{a}}$ & $134 \pm 12^{\mathrm{ab}}$ \\
\hline & Livestock & $58 \pm 12^{\mathrm{b}}$ & $50 \pm 8^{\mathrm{b}}$ & $131 \pm 14^{\mathrm{a}}$ \\
\hline & Off farm & $312 \pm 55^{\mathrm{a}}$ & $377 \pm 68^{\mathrm{a}}$ & $91 \pm 7^{\mathrm{b}}$ \\
\hline \multirow[t]{4}{*}{ Eastern Plateau } & Tree & $5 \pm 1^{\mathrm{c}}$ & $23 \pm 3^{b}$ & $128 \pm 9^{\mathrm{a}}$ \\
\hline & Crop & $124 \pm 13^{\mathrm{c}}$ & $322 \pm 35^{\mathrm{b}}$ & $651 \pm 54^{\mathrm{a}}$ \\
\hline & Livestock & $10 \pm 1^{\mathrm{b}}$ & $59 \pm 13^{\mathrm{a}}$ & $83 \pm 10^{\mathrm{a}}$ \\
\hline & Off farm & $430 \pm 60^{\mathrm{a}}$ & $678 \pm 120^{\mathrm{a}}$ & $556 \pm 131^{\mathrm{a}}$ \\
\hline \multirow[t]{4}{*}{ Eastern Savannah } & Tree & $0^{\mathrm{b}}$ & $6 \pm 2^{\mathrm{a}}$ & $2 \pm 0.1^{\mathrm{b}}$ \\
\hline & Crop & $298 \pm 26^{\mathrm{b}}$ & $530 \pm 51^{\mathrm{b}}$ & $1154 \pm 109^{\mathrm{a}}$ \\
\hline & Livestock & $5 \pm 1^{\mathrm{b}}$ & $31 \pm 7^{\mathrm{b}}$ & $212 \pm 48^{\mathrm{a}}$ \\
\hline & Off farm & $1362 \pm 234^{\mathrm{a}}$ & $304 \pm 39^{\mathrm{b}}$ & $575 \pm 94^{\mathrm{b}}$ \\
\hline \multirow[t]{4}{*}{ Volcanic Highland } & Tree & $1 \pm 0.1^{\mathrm{b}}$ & $2 \pm 1^{\mathrm{b}}$ & $40 \pm 6^{\mathrm{a}}$ \\
\hline & Crop & $277 \pm 29^{\mathrm{a}}$ & $265 \pm 19^{\mathrm{a}}$ & $319 \pm 17^{\mathrm{a}}$ \\
\hline & Livestock & $153 \pm 23^{\mathrm{a}}$ & $212 \pm 23^{\mathrm{a}}$ & $177 \pm 23^{\mathrm{a}}$ \\
\hline & Off farm & $103 \pm 8^{b}$ & $164 \pm 17^{\mathrm{b}}$ & $265 \pm 32^{\mathrm{a}}$ \\
\hline
\end{tabular}


Fig. 2 Contribution of the four farm income sources to total income across farms in the survey. Farms without tree income were first sorted by decreasing off-farm income, followed by income from trees for all other farms

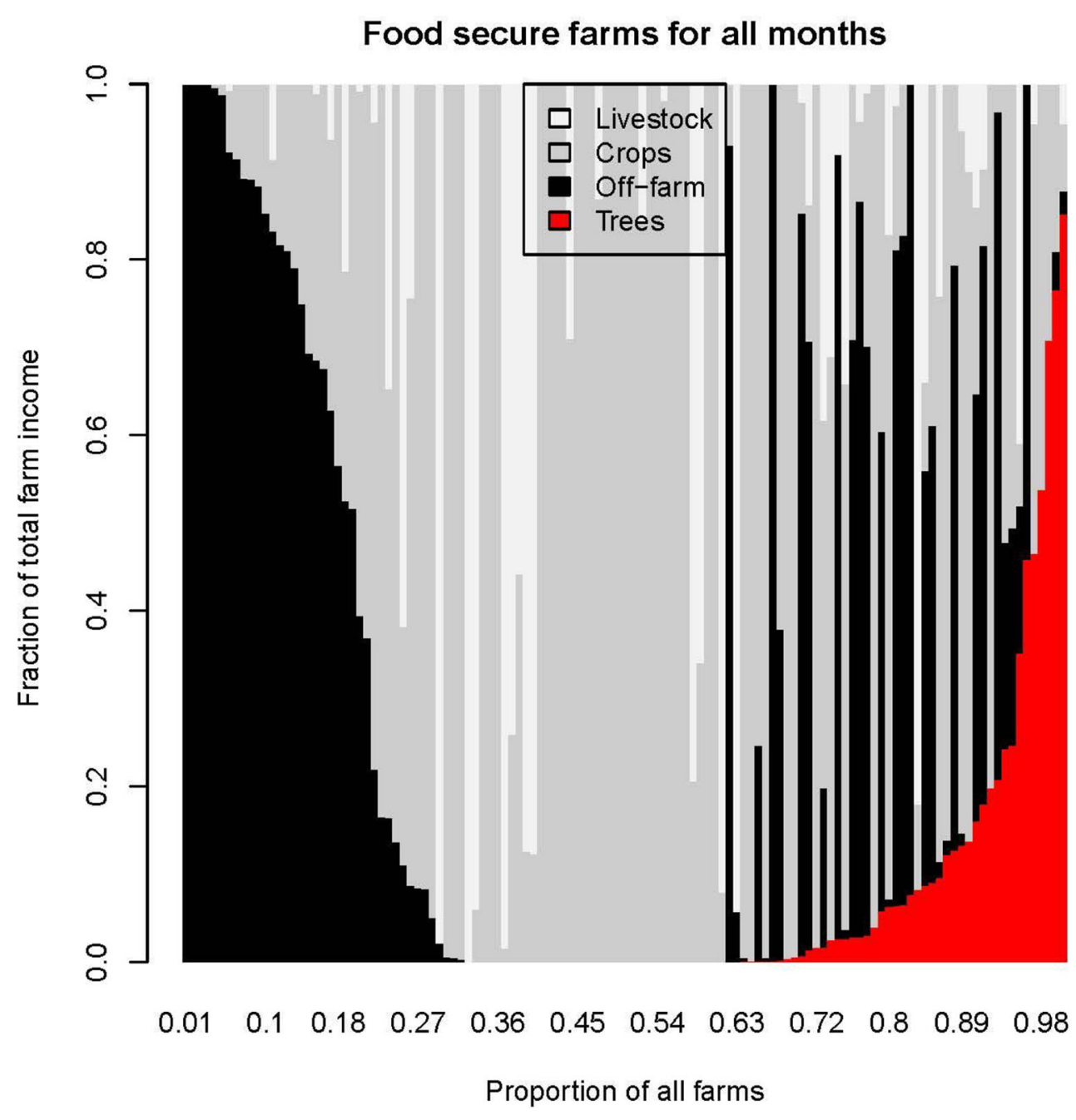

Food security probability increased with increasing tree density on-farm and increasing farm size. Farmers with an average of 1 ha and with more than 175 trees/ha were the most food secure while those with farms around 0.25 ha and with lower tree density, were the least food secure. The density of trees had a large impact on the food security of households of 1 ha, a modest impact for farms of 0.5 ha and no difference for the smaller farms of 0.25 ha. Nevertheless, the trend of food security probability across the year remained the same for all the agroforestry practice types showing the lowest food security in April and November (Fig. 3).

In model 1, most variation in household food security was explained by farm size, the month of the year, followed by crop income (Table 5). With the exception of livestock income and crop productivity, all other factors had a significant impact on food security. Larger farms were more food secure than smaller farms. The interactions between farm size and agroecologies, and between number of trees and agroecologies were also significant. This implies that the influence of number of on-farm trees on food security is mediated by farm size, positively. In the 2nd GLM, tree income was a significant factor in explaining differences in food security, although interactions between income categories and agroecologies indicate strong regional differences (Table 6). We found a negative association between tree income and food security in all regions, possibly indicating that food insecure farmers are selling more wood products than food secure farmers. Income from crops had a positive impact on food security in all regions, possibly indicating that food secure farmers are selling more crop products than food insecure farmers. Off farm income tended to have a negative association with food security in regions with smaller farm sizes possibly indicating that food insecure farmers in these regions tend to depend more on wages than food secure farmers (Table 6). 
Table 4 Assets owned (USD) as a function of agroforestry practice levels (LAP: low practitioners, MAP: medium practitioners, HAP: high practitioners). Means followed by the same letter in the same agroecology and the same asset type do not differ significantly at $\alpha=0.05$. Standard errors are given after the signs ' \pm '

\begin{tabular}{|c|c|c|c|c|}
\hline Agroecology & Assets (USD) & LAP & MAP & HAP \\
\hline \multirow{4}{*}{$\begin{array}{l}\text { Buberuka } \\
\text { Highland }\end{array}$} & Domestic & $97 \pm 27^{\mathrm{a}}$ & $1 \pm 0.1^{\mathrm{b}}$ & $67 \pm 14^{\mathrm{a}}$ \\
\hline & Communication & $44 \pm 3^{b}$ & $46 \pm 3^{\mathrm{b}}$ & $70 \pm 5^{\mathrm{a}}$ \\
\hline & Transport & $10 \pm 2^{\mathrm{a}}$ & $10 \pm 2^{\mathrm{a}}$ & $14 \pm 2^{\mathrm{a}}$ \\
\hline & Farm & $15 \pm 1^{\mathrm{ab}}$ & $11 \pm 1^{\mathrm{b}}$ & $20 \pm 3^{\mathrm{a}}$ \\
\hline \multirow{4}{*}{$\begin{array}{l}\text { Central } \\
\text { Plateau }\end{array}$} & Domestic & $206 \pm 46^{\mathrm{b}}$ & $447 \pm 71^{\mathrm{a}}$ & $125 \pm 33^{\mathrm{b}}$ \\
\hline & Communication & $48 \pm 2^{\mathrm{b}}$ & $58 \pm 3^{\mathrm{a}}$ & $54 \pm 2^{\mathrm{ab}}$ \\
\hline & Transport & $5 \pm 1^{\mathrm{b}}$ & $11 \pm 1^{\mathrm{b}}$ & $28 \pm 4^{\mathrm{a}}$ \\
\hline & Farm & $19 \pm 1^{b}$ & $64 \pm 14^{\mathrm{b}}$ & $116 \pm 19^{a}$ \\
\hline \multirow[t]{4}{*}{ Congo Nile } & Domestic & $338 \pm 57^{\mathrm{a}}$ & $70 \pm 14^{\mathrm{b}}$ & $255 \pm 50^{\mathrm{a}}$ \\
\hline & Communication & $47 \pm 5^{\mathrm{b}}$ & $59 \pm 5^{\mathrm{b}}$ & $83 \pm 3^{a}$ \\
\hline & Transport & $129 \pm 32^{\mathrm{a}}$ & $30 \pm 7^{\mathrm{b}}$ & $10 \pm 2^{\mathrm{b}}$ \\
\hline & Farm & $16 \pm 1^{\mathrm{a}}$ & $16 \pm 1^{\mathrm{a}}$ & $13 \pm 1^{\mathrm{a}}$ \\
\hline \multirow{4}{*}{$\begin{array}{l}\text { Eastern } \\
\text { Plateau }\end{array}$} & Domestic & $176 \pm 18^{\mathrm{b}}$ & $250 \pm 35^{\mathrm{ab}}$ & $371 \pm 57^{\mathrm{a}}$ \\
\hline & Communication & $63 \pm 3^{\mathrm{a}}$ & $71 \pm 4^{\mathrm{a}}$ & $68 \pm 3^{\mathrm{a}}$ \\
\hline & Transport & $125 \pm 24^{\mathrm{a}}$ & $139 \pm 24^{\mathrm{a}}$ & $72 \pm 7^{\mathrm{b}}$ \\
\hline & Farm & $18 \pm 1^{\mathrm{b}}$ & $20 \pm 1^{\mathrm{b}}$ & $48 \pm 4^{\mathrm{a}}$ \\
\hline \multirow{4}{*}{$\begin{array}{l}\text { Eastern } \\
\text { Savannah }\end{array}$} & Domestic & $334 \pm 68^{a}$ & $483 \pm 62^{\mathrm{a}}$ & $387 \pm 60^{\mathrm{a}}$ \\
\hline & Communication & $78 \pm 4^{\mathrm{a}}$ & $60 \pm 2^{\mathrm{b}}$ & $83 \pm 4^{\mathrm{a}}$ \\
\hline & Transport & $67 \pm 6^{\mathrm{a}}$ & $33 \pm 2^{\mathrm{b}}$ & $63 \pm 7^{\mathrm{a}}$ \\
\hline & Farm & $12 \pm 1^{\mathrm{c}}$ & $17 \pm 1^{\mathrm{b}}$ & $24 \pm 2^{\mathrm{a}}$ \\
\hline \multirow{4}{*}{$\begin{array}{l}\text { Volcanic } \\
\text { Highland }\end{array}$} & Domestic & $554 \pm 72^{\mathrm{a}}$ & $395 \pm 44^{\mathrm{a}}$ & $457 \pm 52^{\mathrm{a}}$ \\
\hline & Communication & $62 \pm 2^{\mathrm{b}}$ & $64 \pm 3^{\mathrm{b}}$ & $83 \pm 4^{\mathrm{a}}$ \\
\hline & Transport & $0^{\mathrm{b}}$ & $7 \pm 1^{\mathrm{a}}$ & $9 \pm 1^{\mathrm{a}}$ \\
\hline & Farm & $32 \pm 3^{b}$ & $27 \pm 1^{\mathrm{b}}$ & $43 \pm 3^{\mathrm{a}}$ \\
\hline
\end{tabular}

Food self-sufficiency here refers to the ability to cover the household's calorific needs through the household's own production. Most farms were not food self-sufficient: only farmers in HAP and MAP types in the Eastern Savannah agroecology were self-sufficient (Fig. 4) while all types in other agroecologies were not self-sufficient. Coverage of the household caloric needs was significantly different between the types of agroforestry practitioners on-farm with $51 \%$ coverage coming from household own food production and $49 \%$ coming from generated income. The highest food insecurity was found in Congo Nile, Buberuka Highland and Volcanic highland where none of the types could cover all their caloric needs (Fig. 4). Households in the Buberuka Highland and Congo Nile agroecologies with more trees on farm also had smaller farm sizes (Table 2) and were more food insecure (Fig. 4). When comparing farms in the same agroecology, households in the HAP type were more food secure than other types, in four out of the six agroecologies probably due to higher production of food on farm and in three out of six due to more purchased food (Fig. 4).

The influence of farm size and trees on food security differed strongly between the agroecologies. Differences between farms of $0.25,0.5$ and 1.0 ha were relatively small in Central and Eastern Plateau and Volcanic Highlands, whereas farm size effects were much larger in Congo Nile, Eastern Savannah and Buberuka Highlands. The influence of trees on food security varied between agroecologies, increasing tree density was associated with a higher probability of food security in Congo Nile, but in a lower food security in Bubureka Highlands (Fig. 5).

\section{Discussion}

\subsection{Tree income can be perceived as a "safety net" for the poorest farmers}

Households in the HAP group were more food secure than those in MAP and LAP groups, mainly due to higher income from crops but with limited contribution of income from trees. Income from trees was minimal and not well related to the types of agroforestry practitioners in some agroecologies, suggesting that trees on-farm are probably kept by farmers for other reasons (e.g., own consumption of firewood and fruits, shade, and erosion control). Yet, for about $12 \%$ of farmers, tree products contributed more than $20 \%$ to their income, where food insecure farmers were more often selling tree products for income than food secure farmers. In this way trees may be perceived as a "safety net" to meet the needs of the poorest households, with smallest farms and lowest income.

Though the income contribution from trees was generally small in absolute terms, farmers in agroecologies of the western part of the country (Congo Nile, Volcanic highland, Burberuka Highland and Central Plateau) seemed to earn a substantial proportion of their income from trees in contrast to their counterparts in the East (Eastern Savanna and Eastern Plateau). This may reflect the value of wood products and the hypothesized importance of the ability to sell wood for the food security of farm households when on-farm trees are in a sufficient number to be marketable (Ndayambaje et al. 2014). Within a particular agroecology, household's food 
Fig. 3 Monthly probability of food security as a function of farm size category (1.0 ha, 0.5 ha, and $0.25 \mathrm{ha})$ and tree densities $(>175$ trees/ha, $<175$ trees/ha, and $<35$ trees/ha)

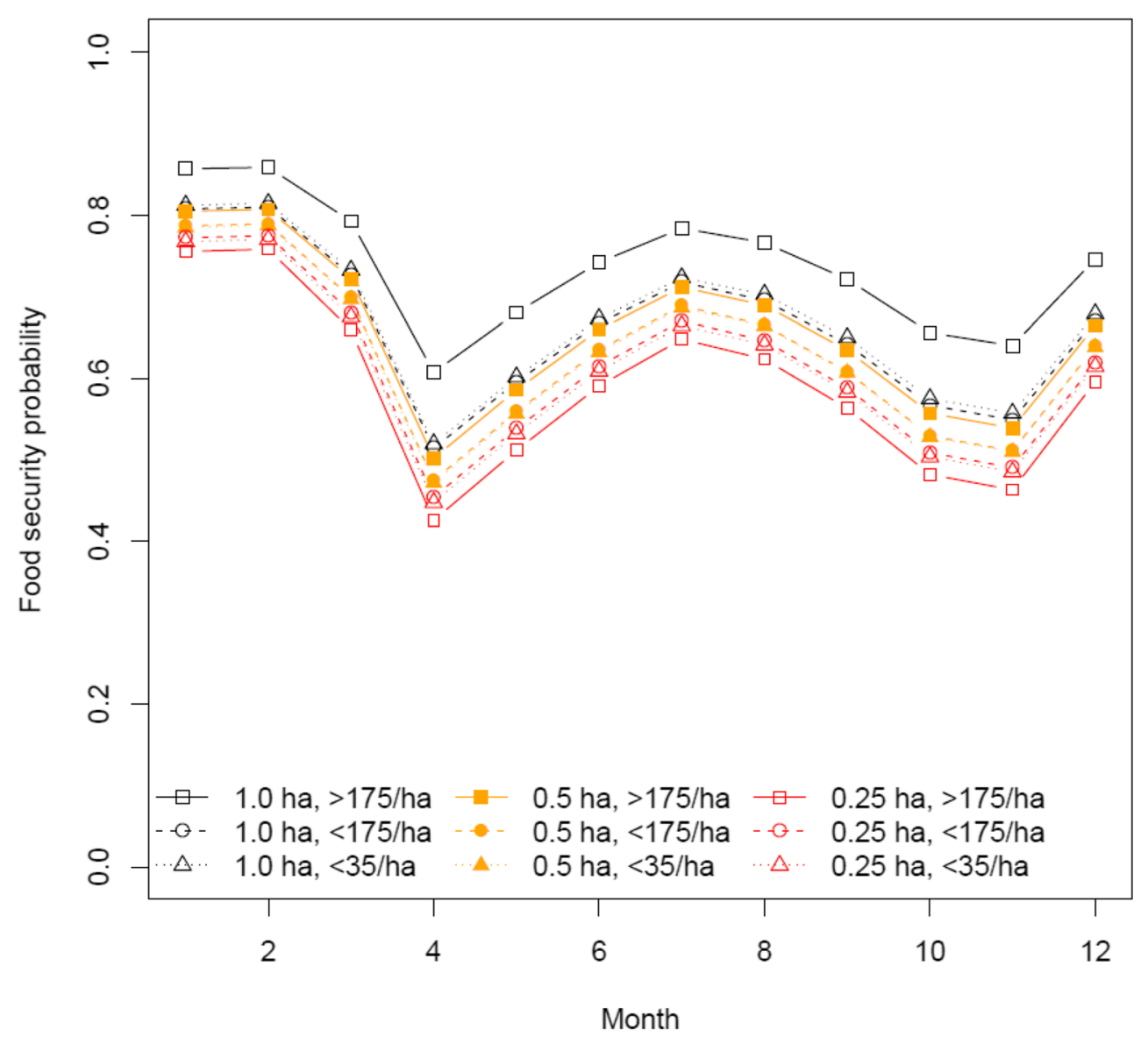

security increased with increasing numbers of on-farm trees but was not driven by tree income. Indeed, within each agroecology, HAP households had usually a higher crop and livestock income than MAP and LAP households, suggesting that the improved food security of households with higher number of on-farm trees is associated to their higher overall farm income while the contribution of tree income was small. Coulibaly et al. (2017) recently found that agroforestry adoption increased income from both crops and tree products and therefore positively impacted household food security in Malawi. Our study did not assess the proportion of selfconsumed tree products but from the validation workshops and expert knowledge, it is commonly understood that in Rwanda, the biggest share of on-farm tree products are selfconsumed while the surplus is sold on market. Our study confirms this, suggesting that on-farm trees are mostly used for self-consumption and not necessarily sold, in contrast to crops and livestock which form an important source of income for rural households. Though income from trees is lower than income from crops and livestock, food insecure households tend to rely more on tree income than food secure households who mainly depend on crops and livestock income. Thus, income from trees can be perceived as a "safety net" for the poorest households.

\subsection{More on-farm trees are found in agroecologies challenged by small farmland and food insecurity}

Due to contrasted biophysical (e.g., topography, rainfall, temperature and soil types) and socio-economic conditions, farm size was larger and food security was higher in the East than in the West of the country (NISR 2012) while the number of trees per household was higher in the West than in the East. In the eastern part of Rwanda (Eastern Savannah and Eastern Plateau) where households have relatively more land, HAP farmers had larger farms and a higher crop income than MAP or LAP farmers. Thus, despite the lowest income from trees as compared to the other agroecologies, the HAP households in the eastern parts of Rwanda were wealthier (e.g., with larger farms and higher overall income) and therefore were 
Table 5 Results of the analysis of deviance of the structural GLM model 1 for explaining the effects of households' number of trees, farm size, month of the year, agroecology factors, and income sources on food security of farm households

\begin{tabular}{|c|c|c|c|}
\hline Model factors & $\mathrm{DF}$ & Deviance & $\mathrm{P}$ \\
\hline \multicolumn{4}{|l|}{ Model 1} \\
\hline Farm size & 1 & 259.49 & $<0.0001$ \\
\hline Number of trees & 1 & 13.48 & 0.00024 \\
\hline Agroecology & 5 & 28.86 & $<0.0001$ \\
\hline Month & 11 & 195.56 & $<0.0001$ \\
\hline Crop income & 1 & 129.04 & $<0.0001$ \\
\hline Livestock income & 1 & 3.229 & 0.07236 \\
\hline Off-farm income & 1 & 71.509 & $<0.0001$ \\
\hline Crop productivity & 1 & 1.065 & 0.30201 \\
\hline Farm size: Number of trees & 1 & 4.834 & 0.0279 \\
\hline Farm size: Agroecology & 5 & 99.991 & $<0.0001$ \\
\hline Number of trees: Agroecology & 5 & 65.386 & $<0.0001$ \\
\hline Farm size: Number of trees: Agroecology & 5 & 24.305 & 0.00019 \\
\hline \multicolumn{4}{|l|}{ Eastern Savannah } \\
\hline Farm size & 1 & 77.41 & $<0.0001$ \\
\hline Number of trees & 1 & 53.56 & $<0.0001$ \\
\hline Farm size: Number of trees & 1 & 0.85 & 0.357 \\
\hline \multicolumn{4}{|l|}{ Eastern Plateau } \\
\hline Farm size & 1 & 12.47 & 0.0004 \\
\hline Number of trees & 1 & 8.29 & 0.0039 \\
\hline Farm size: Number of trees & 1 & 0.72 & 0.3964 \\
\hline \multicolumn{4}{|l|}{ Buberuka highland } \\
\hline Farm size & 1 & 85.6 & $<0.0001$ \\
\hline Number of trees & 1 & 0.18 & 0.6754 \\
\hline Farm size: Number of trees & 1 & 0.53 & 0.4674 \\
\hline \multicolumn{4}{|l|}{ Volcanic highland } \\
\hline Farm size & 1 & 18.17 & $<0.0001$ \\
\hline Number of trees & 1 & 11.41 & 0.0007 \\
\hline Farm size: Number of trees & 1 & 3.29 & 0.0697 \\
\hline \multicolumn{4}{|l|}{ Central plateau } \\
\hline Farm size & 1 & 33.05 & $<0.0001$ \\
\hline Number of trees & 1 & 11.34 & 0.0008 \\
\hline Farm size: Number of trees & 1 & 0.243 & 0.6217 \\
\hline \multicolumn{4}{|l|}{ Congo Nile } \\
\hline Farm size & 1 & 123.51 & $<0.0001$ \\
\hline Number of trees & 1 & 3.31 & 0.0687 \\
\hline Farm size: Number of trees & 1 & 21.10 & $<0.0001$ \\
\hline
\end{tabular}

Not significant effects $(p<0.05)$ are shown in bold

more food secure than MAP and LAP. In the western part of the country which has a very hilly topography (Congo Nile Crest, Buberuka Highland and volcanic highland) and with
Table 6 Summary of the results of the functional GLM model 2 for explaining the effects tree, crop, livestock and off-farm incomes and crop productivity and agroecology factors on food security of farm households

\begin{tabular}{|c|c|c|c|c|}
\hline Model factors & $\mathrm{F}$ & Estimate & $\mathrm{P}$ & $\mathrm{DF}$ \\
\hline \multicolumn{5}{|l|}{ Model 2} \\
\hline Tree income & 48 & -0.01 & $<0.0001$ & 1 \\
\hline Crop income & 277 & 0.007 & $<0.0001$ & 1 \\
\hline Livestock income & 8 & 0.002 & 0.0047 & 1 \\
\hline Off-farm income & 74 & -0.0005 & $<0.0001$ & 1 \\
\hline Crop productivity & 1.3 & -0.003 & 0.2554 & 1 \\
\hline Tree income $\times$ Agroecology & 3.7 & & 0.6009 & 5 \\
\hline Crop income $\times$ Agroecology & 119 & & $<0.0001$ & 5 \\
\hline Livestock income $\times$ Agroecology & 50 & & $<0.0001$ & 5 \\
\hline Off-farm income $\times$ Agroecology & 31 & & $<0.0001$ & 5 \\
\hline Crop productivity $\times$ Agroecology & 27 & & $<0.0001$ & 5 \\
\hline \multicolumn{5}{|l|}{ Eastern Savannah } \\
\hline Tree income & 16 & -0.5 & $<0.0001$ & 1 \\
\hline Crop income & 73 & 0.002 & $<0.0001$ & 1 \\
\hline Livestock income & 27 & 0.017 & $<0.0001$ & 1 \\
\hline Off-farm income & 43 & 0.002 & $<0.0001$ & 1 \\
\hline Crop productivity & 0.1 & -0.001 & 0.7205 & 1 \\
\hline \multicolumn{5}{|l|}{ Eastern Plateau } \\
\hline Tree income & 2.4 & -0.002 & 0.1216 & 1 \\
\hline Crop income & 29 & 0.0002 & $<0.0001$ & 1 \\
\hline Livestock income & 11 & 0.007 & 0.0008 & 1 \\
\hline Off-farm income & 19 & 0.0003 & $<0.0001$ & 1 \\
\hline Crop productivity & 1.3 & 0.001 & 0.2613 & 1 \\
\hline \multicolumn{5}{|l|}{ Buberuka highland } \\
\hline Tree income & 4.5 & -0.02 & 0.0339 & 1 \\
\hline Crop income & 109 & 0.006 & $<0.0001$ & 1 \\
\hline Livestock income & 0.029 & 0.007 & 0.8638 & 1 \\
\hline Off-farm income & 4.9 & -0.0001 & 0.0263 & 1 \\
\hline Crop productivity & 3.9 & -0.005 & 0.049 & 1 \\
\hline \multicolumn{5}{|l|}{ Volcanic highland } \\
\hline Tree income & 9.9 & -0.001 & 0.0016 & 1 \\
\hline Crop income & 36 & 0.0009 & $<0.0001$ & 1 \\
\hline Livestock income & 0.03 & -0.00001 & 0.8539 & 1 \\
\hline Off-farm income & 12.5 & 0.0008 & 0.0004 & 1 \\
\hline Crop productivity & 8.8 & 0.004 & 0.003 & 1 \\
\hline \multicolumn{5}{|l|}{ Central plateau } \\
\hline Tree income & 19 & -0.001 & $<0.0001$ & 1 \\
\hline Crop income & 38 & 0.001 & $<0.0001$ & 1 \\
\hline Livestock income & 3.5 & 0.0006 & 0.0616 & 1 \\
\hline Off-farm income & 6.7 & -0.00007 & 0.0097 & 1 \\
\hline Crop productivity & 2.8 & -0.002 & 0.0929 & \\
\hline \multicolumn{5}{|l|}{ Congo Nile } \\
\hline Tree income & 33 & -0.002 & $<0.0001$ & 1 \\
\hline Crop income & 73 & 0.005 & $<0.0001$ & 1 \\
\hline Livestock income & 24 & 0.003 & $<0.0001$ & 1 \\
\hline Off-farm income & 0.04 & -0.001 & 0.8353 & 1 \\
\hline Crop productivity & 11.4 & -0.008 & 0.0007 & 1 \\
\hline
\end{tabular}

Not significant effects $(p<0.05)$ are shown in bold

more on-farm trees, most households were food insecure possibly due to small farmlands and lower off-farm income.

This study found no direct relationship between asset endowment and agroforestry practice type. However, farm size, crop and livestock income - which are the most common wealth indicators for farm households in Rwanda - were 
Fig. 4 Percentage coverage of energy needs of households in different categories of agroforestry practice and in different agroecologies of Rwanda

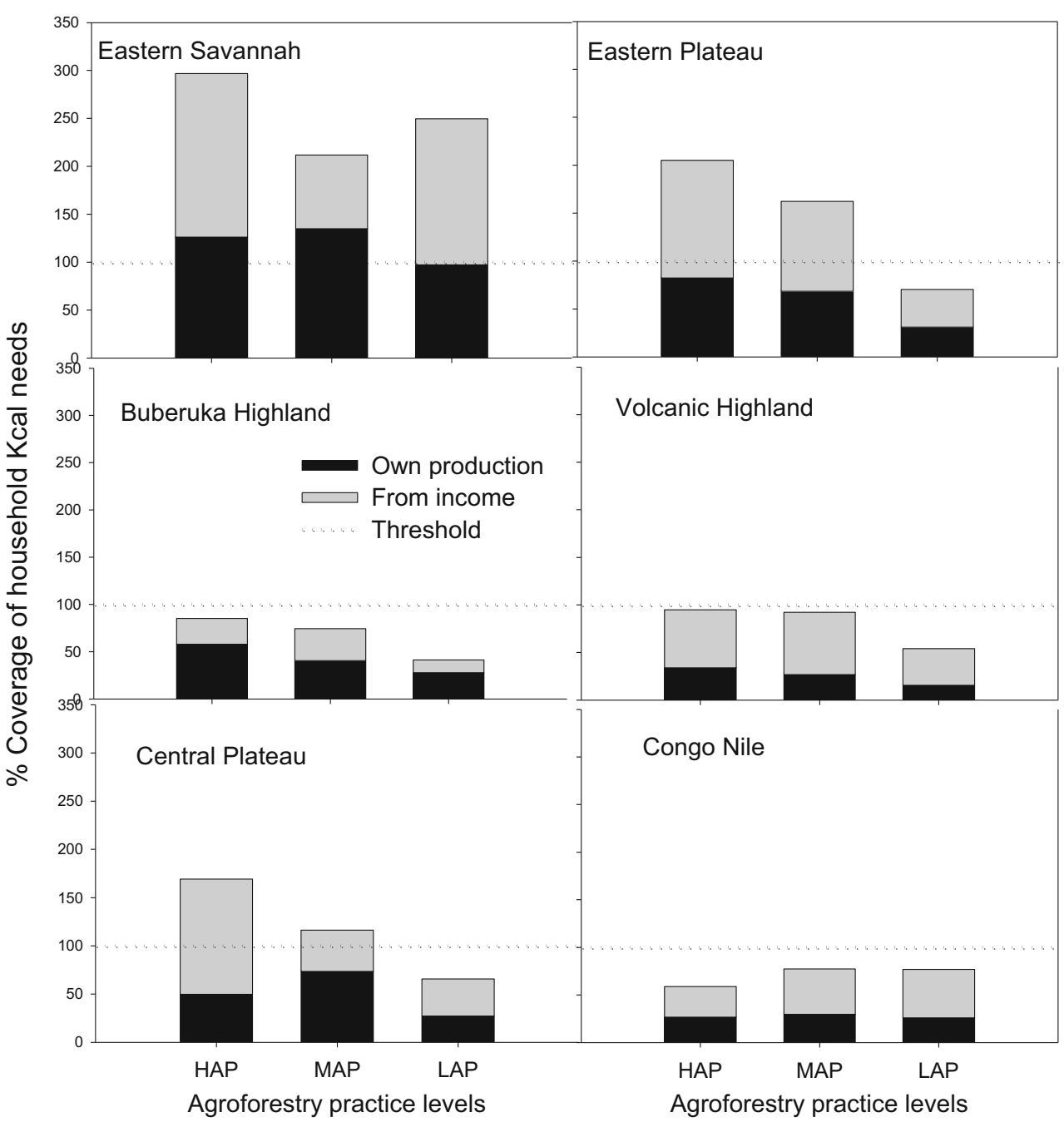

correlated to the number of on-farm trees in most of the agroecologies. Within the same agroecology, food security increased with increasing farm size and households with more trees were more food secure than those with less. Within the same agroecology, households with more income from trees as compared to their counterparts had also more income from crops and livestock in contrast to what was observed in Ethiopia where income from trees increased at the expense of income from crops (Sida et al. 2018). In the study sites, trees were important in providing firewood, timber, and shade but could come with the cost of lower productivity especially near trees.

Though dependent on farm size, on-farm trees seem profitable when farmers integrate crops and livestock since income from trees appeared positively associated with crop and livestock income (Bucagu 2013; Beedy et al. 2013). There is a need for more detailed studies to assess the biophysical and socio-economic contexts in order to understand the role of agroforestry on net farm income and household food security. Assessment of food security is notoriously difficult (Barrett 2010). Our analysis is based on self-reported sufficiency in the quantity and diversity of food, and may therefore be biased (Tadesse et al. 2020). However, for comparative analysis such as in our paper, this bias is unlikely to affect conclusions.

\section{Conclusion}

The present study investigated whether farmers with more trees on their farm were more food secure than those with less trees in the six agroecological zones of Rwanda. Large differences between agroecological zones were observed for both food self-sufficiency and food security. Households with 


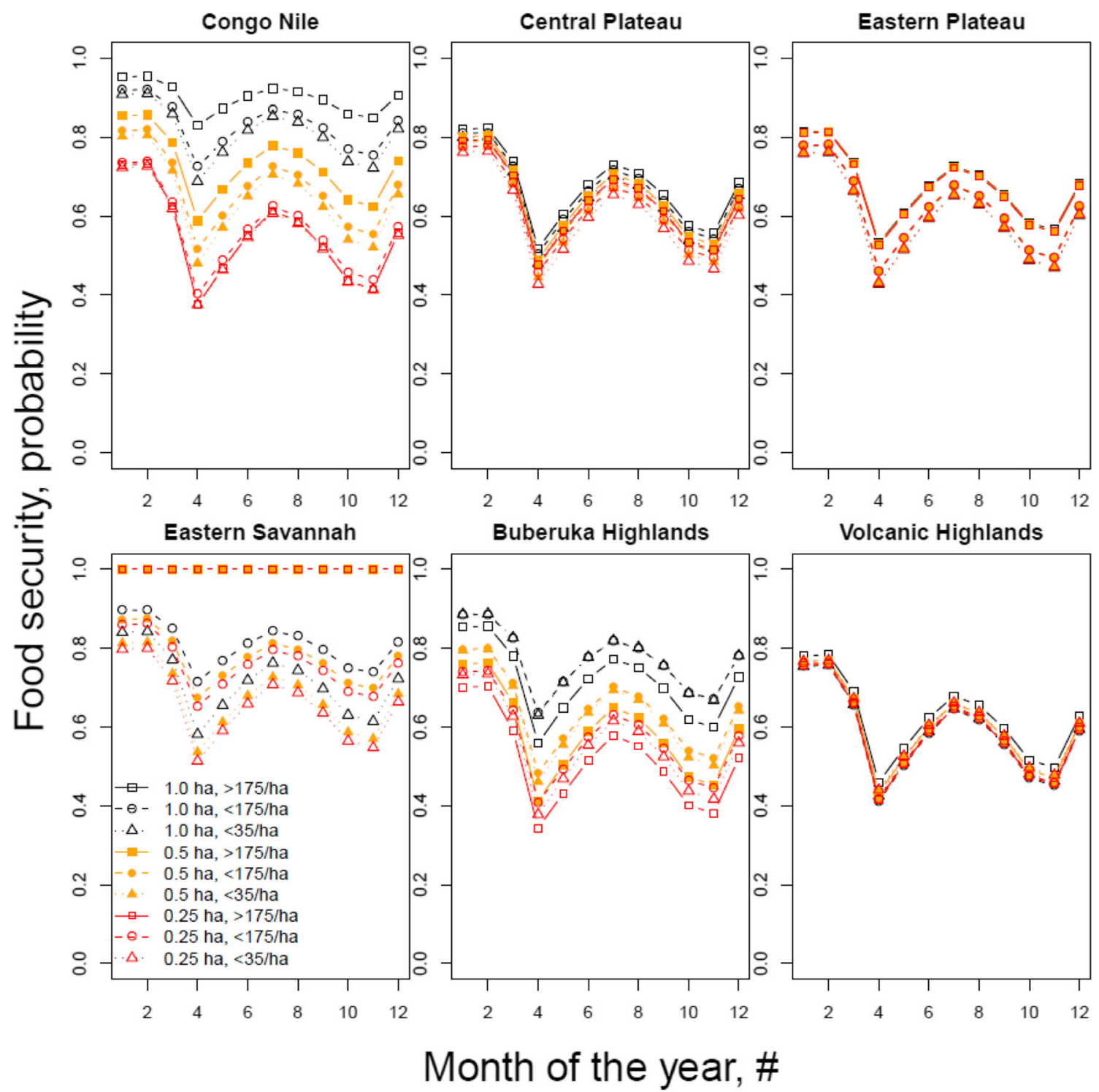

Fig. 5 Monthly probability of food security as a function of farm size category ( 1 ha, 0.5 ha, and 0.25 ha) and tree densities $(>175$ trees/ha, $<175$ trees/ha, and $<35$ trees/ha) for each agroecology

larger farms depended more on crop and livestock income and were more food secure than those with smaller farms who depended more on tree income. The proportion of income that came from tree products was more than $20 \%$ for about $12 \%$ of the farmers, with food insecure farm households relying more on income from tree products than food secure farm households. The influence of tree density on household-reported food sufficiency varied between regions when accounting for farm size. In most cases, higher tree density did not result in higher income from trees at the level expected, suggesting that trees on-farm are mostly used to meet the demand of households in firewood, fruits and other tree products. In each agroecology, better coverage of caloric needs was found in the type of households with more trees mainly through food purchase as they were usually wealthier (e.g., with larger farms and higher income) than the rest. The lack of a clear relationship between asset endowment and levels of agroforestry practice while farm size and income were significantly different between HAP, MAP and LAP, suggests that assets may not be the best indicator of wealth for Rwandan farm households. Our results suggest that within the same agroecology, farm households with more land most probably grow trees on- 
farm to increase their self-sufficiency in fuelwood, fruits and other tree products rather than growing them for markets. Future research should address improvements in commercialization of on-farm tree products to generate income and thus impact on food security of smallholders.

Acknowledgements This study is based on a larger study entitled "Taking to scale tree-based systems that enhance food security, improve resilience to climate change, and sequester carbon in Rwanda," conducted by the World Agroforestry Centre (ICRAF) and supported by PROFOR, BNPP and TerrAfrica. The study was also supported by the project 'Trees for Food Security' (FSC/2012/014), made possible by the generous support of the Australian Centre for International Agricultural Research (ACIAR) and CRP MAIZE (www.maize.org). Any opinions, findings, conclusion or recommendations expressed in this publication are those of the authors and do not necessarily reflect the view of ICRAF, ACIAR and CRP MAIZE.

\section{Compliance with ethical standards}

Conflict of interest The authors declared that they have no conflict of interest.

Open Access This article is licensed under a Creative Commons Attribution 4.0 International License, which permits use, sharing, adaptation, distribution and reproduction in any medium or format, as long as you give appropriate credit to the original author(s) and the source, provide a link to the Creative Commons licence, and indicate if changes were made. The images or other third party material in this article are included in the article's Creative Commons licence, unless indicated otherwise in a credit line to the material. If material is not included in the article's Creative Commons licence and your intended use is not permitted by statutory regulation or exceeds the permitted use, you will need to obtain permission directly from the copyright holder. To view a copy of this licence, visit http://creativecommons.org/licenses/by/4.0/.

\section{References}

Barrett, C. B. (2010). Measuring food insecurity. Science, 327(5967), $825-828$.

Beedy, T., Ajayi, O., Sileshi, G., Kundhlande, G., Chiundu, G., \& Simons, A. (2013). Scaling up agroforestry to achieve food security and environmental protection among smallholder farmers in Malawi. Field Actions Science Reports. The journal of field actions (Special Issue 7).

Brown, D. G., Robinson, D. T., French, N. H., \& Reed, B. C. (2013). Land use and the carbon cycle: advances in integrated science, management, and policy. Cambridge: Cambridge University Press.

Bucagu, C. (2013). Tailoring agroforestry technologies to the diversity of Rwandan smallholder agriculture. Wageningen: Wageningen University Netherlands.

Coulibaly, J. Y., Chiputwa, B., Nakelse, T., \& Kundhlande, G. (2017). Adoption of agroforestry and the impact on household food security among farmers in Malawi. Agricultural Systems, $155,52-69$.

Dennis, G., Akinnifesi, P., Ajayi, F. K., Oluyede, C., Weldesemayat, S., Mowo, J., et al. (2010). Evergreen agriculture: A robust approach to sustainable food security in Africa. Food Security, 2(3), 197-214. https://doi.org/10.1007/s12571-010-0070-7.
Dixon, J. A., Gibbon, D. P., \& Gulliver, A. (2001). Farming systems and poverty: improving farmers' livelihoods in a changing world. Rome: FAO.

Djimde, M. (1988). Potentiel agroforestier dans les systemes d'utilisation des sols des hautes terres d'Afrique de l'Est arégime pluviométrique bimodal: Rwanda (p. 121). Nairobi: International Centre for Research in Agroforestry.

Drechsel, P., Gyiele, L., Kunze, D., \& Cofie, O. (2001). Population density, soil nutrient depletion, and economic growth in sub-Saharan Africa. Ecological Economics, 38(2), 251-258.

FAO, IFAD, UNICEF, WFP, \& WHO. (2019). The State of Food Security and Nutrition in the World 2019. Safeguarding against economic slowdowns and downturns. Rome: FAO.

Garrity, D. (2012). Agroforestry and the future of global land use. In P. K. R. Nair \& D. Garrity (Eds.), Agroforestry - the future of global land use (pp. 21-27). Dordrecht: Springer Netherlands.

Hjelm, L., Williams, K., \& Moris, L. (2015). Comprehensive food security and vulnerability analysis and nutrition survey Rwanda. Kigali: Government of Rwanda and United Nations-Rwanda.

ICRAF (2013). Strategy 2013-2022: Transforming Lives and Landscapes with Trees. Nairobi: World Agroforestry Centre.

Iiyama, M., Mukuralinda, A., Ndayambaje, J. D., Musana, B., Ndoli, A., Mowo, J. G., et al. (2018a). Tree-based ecosystem approaches (TBEAs) as multi-functional land management strategiesEvidence from Rwanda. Sustainability, 10(5), 1360.

Iiyama, M., Mukuralinda, A., Ndayambaje, J. D., Musana, B. S., Ndoli, A., Mowo, J. G., Garrity, D., Ling, S., \& Ruganzu, V. (2018b). Addressing the paradox-the divergence between smallholders' preference and actual adoption of agricultural innovations. International Journal of Agricultural Sustainability, 16(6), 472-485.

Kho, R. M. (2000). On crop production and the balance of available resources. Agriculture Ecosystems \& Environment, 80(1), 71-85.

Kristjanson, P., Neufeldt, H., Gassner, A., Mango, J., Kyazze, F. B., Desta, S., Sayula, G., Thiede, B., Förch, W., Thornton, P. K., \& Coe, R. (2012). Are food insecure smallholder households making changes in their farming practices? Evidence from East Africa. Food Security, 4(3), 381-397.

Leakey, R. (1996). Definition of agroforestry revisited. Agroforestry Today, 8, 5-5.

Mbow, C., Van Noordwijk, M., Luedeling, E., Neufeldt, H., Minang, P. A., \& Kowero, G. (2014). Agroforestry solutions to address food security and climate change challenges in Africa. Current Opinion in Environmental Sustainability, 6, 61-67.

Mukuralinda, A., Ndayambaje, J. D., Iiyama, M., Ndoli, A., Musana, B., Garrity, D. P., \& Ling, S. (2016). Taking to scale tree-based systems in Rwanda to enhance food security, restore degraded land, improve resilience to climate change and sequester carbon. Washington, DC: PROFOR.

Ndayambaje, J., Mugiraneza, T., \& Mohren, G. (2014). Woody biomass on farms and in the landscapes of Rwanda. Agroforestry Systems, $88(1), 101-124$.

Ndoli, A., Baudron, F., Schut, A. G. T., Mukuralinda, A., \& Giller, K. E. (2017). Disentangling the positive and negative effects of trees on maize performance in smallholdings of northern Rwanda. Field Crops Research, 213, 1-11. https://doi.org/10.1016/j.fcr.2017.07.020.

NISR, N. I. o. S. o. R. (2010). National agricultural survey 2008. Kigali: National Institute of Statistics of Rwanda.

NISR (2012). Rwanda comprehensive food security and vulnerability analysis and nutrition survey (p. 126). Kigali.

R Development Core Team. (2014). $R$ : A language and environment for statistical computing (Vol. 2013). Vienna: R foundation for statistical computing.

Sida, T. S., Baudron, F., Hadgu, K., Derero, A., \& Giller, K. E. (2018), Crop vs. tree: Can agronomic management reduce trade-offs in tree- 
crop interactions? Agriculture, Ecosystems \& Environment, 260, 3646.

Stainback, G. A., Masozera, M., Mukuralinda, A., \& Dwivedi, P. (2012). Smallholder agroforestry in Rwanda: A SWOT-AHP analysis. Small-scale Forestry, 11(3), 285-300.

Stoorvogel, J. J., \& Smaling, E. M. A. (1990). Assessment of soil nutrient depletion in Sub-Saharan Africa: 1983-2000 (Vol. 1): Winand Staring Centre Wageningen.

Tadesse, G., Abate, G. T., \& Zewdie, T. (2020). Biases in self-reported food insecurity measurement: A list experiment approach. Food Policy, 92, 101862, https://doi.org/10.1016/j.foodpol.2020.101862.

Von Braun, J. (2007). The world food situtation: new driving forces and required actions. Washington, DC: International Food Policy Research Institute.

Welham, S., Cullis, B., Gogel, B., Gilmour, A., \& Thompson, R. (2004). Prediction in linear mixed models. Australian \& New Zealand Journal of Statistics, 46(3), 325-347.

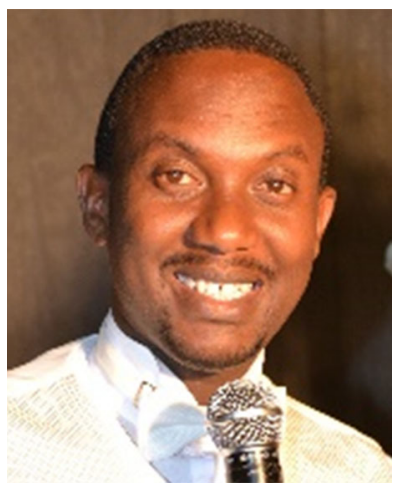

Alain Ndoli is a senior programme officer at the International Union for Conservation of Nature (IUCN) based in Rwanda. Trained as a soil scientist, he specialized in agroforestry and integrated soil fertility management. He started his carrier lecturing at the University of Rwanda and conducting research on reclamation of mined sites. $\mathrm{He}$ holds a $\mathrm{PhD}$ in plant production systems from Wageningen University. Alain's research has mainly focused on tree-crop interactions, soil fertility improvement and farming systems in general. His current interest is in forest landscape restoration across Eastern and Southern Africa where he is involved in projects carried out in Madagascar, Ethiopia, Rwanda, Tanzania, and Mozambique.

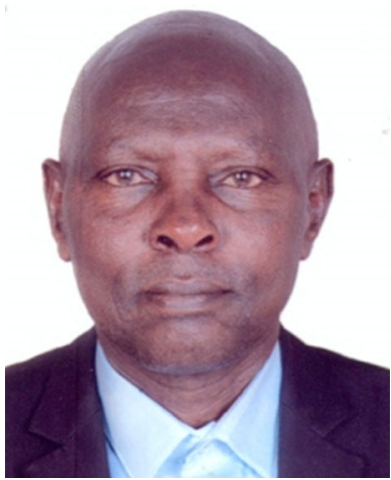

Dr. Athanase Mukuralinda, senior scientist, is a $\mathrm{PhD}$ in agroforestry with experience in soil fertility management including nutrient cycling, tree crop interactions and trees management for increasing crops and tree yield in agroforestry systems. He is ICRAF Country Representative and oversees all ICRAF projects conducted in Rwanda and focus on research in agroforestry and scaling up agroforestry technologies in different contexts in the great lakes region (Rwanda, Burundi and DRC). He has more than 20 years of experience in agroforestry, published several papers in peer review, internal publication, technical reports to various donors, mobilized funds and produced several extension materials. Athanase also co-supervised 4 Ph.D. students conducting Research in Agroforestry, several MSC, under graduate students and organized training for cooperatives involved in agroforestry, Community Based Organization (CBO), field technicians and youth.

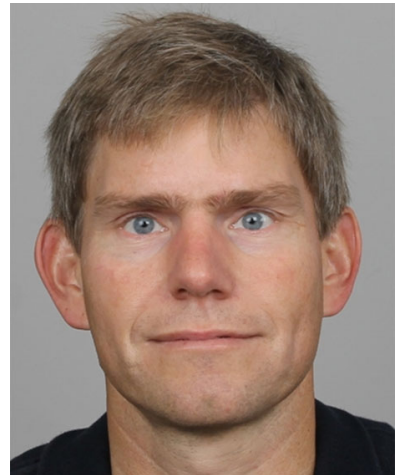

Antonius G.T. Schut is anassociate professor at the Plant Production Systems group of Wageningen University in the Netherlands. After a bachelor in dairy science he graduated as spatial soil scientist. His research include optimization of agricultural systems with sustainable intensification, adapting farm management to local conditions to improve efficiency and minimise environmental impacts. His work combines dynamic modelling of crops and nutrient flows at field and farm scale with spatial datasets including remote sensing. His current research focusses on productivity of smallholder farms and improved circularity of agriculture.

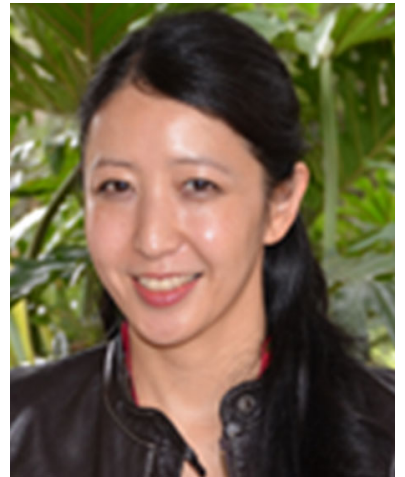

Miyuki liyama With Ph.D. in economics from the University of Tokyo, Miyuki Iiyama has extensive experiences in quantitative and qualitative analyses of integrated farming system evolutions, technological adoption, and sustainable livelihoods in rural Africa. During almost 20-year experience in East and Southern Africa, she has been especially assigned to do research on the evaluation of socio-economic and environmental viability of sustainable agricultural intensification within smallholder systems. Since April 2019, she assumes the position of Research Strategy Office Director at Japan International Research Center for Agricultural Sciences (JIRCAS).

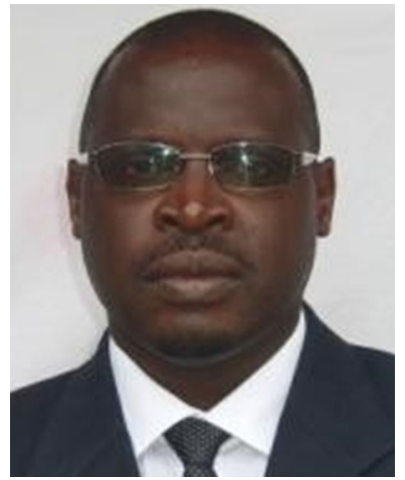

Jean Damascene Ndayambaje holds a Bachelors degree in Forestry Sciences obtained at Sokoine University of Agriculture, Tanzania and MSc. Degree in Forestry (Community Forestry) from Stellenbosch University, South Africa. In 2006, he was admitted to the Sandwish Fellowship Programme of Wageningen University, the Netherlands and joined the Forest Ecology and Forest Management Group for a $\mathrm{PhD}$ study in Agroforestry. In his $\mathrm{PhD}$ research, he assessed trees and woodlots in Rwanda and their role in fuelwood supply. During his career, Ndayambaje occupied various positions in forestry and agroforestry research in Rwanda. He served as the Rwanda focal person for regional networks such as the African Forestry Research Network and Trees on- Farms Network, of the Association for Strenghening Agricultural Reseach in East and Central Africa. Currently, he is the Principal Research Fellow in Agroforestry at Rwanda Agriculture and Animal Resources Development Board as senior researcher and leader of the Agroforetry Research and Technology Transfer Program. 


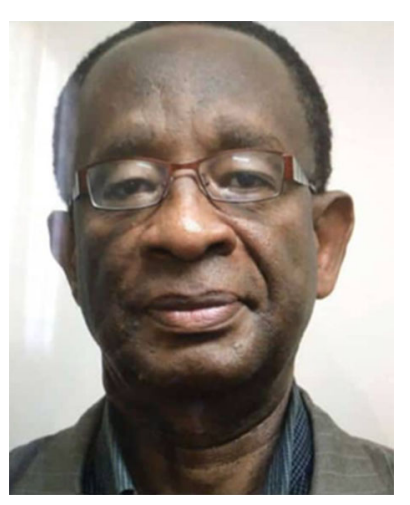

Jeremias Gasper Mowo has over 35 years of professional experience in agricultural research for development in various countries in eastern and southern Africa. He retired from ICRAF (World Agroforestry) in 2018 where he was the Regional Coordinator for eastern and southern Africa. He is currently the CEO of the Association for Landuse, Environmental care, Research and Technology transfer (ALERT) based in Arusha, Tanzania. He is also a Senior Fellow of the Global EverGreening Alliance. Jeremias holds a $\mathrm{PhD}$ in Soil Science from Wageningen University, the Netherlands (2000) and his major area of interest is integrated natural resource management (INRM).

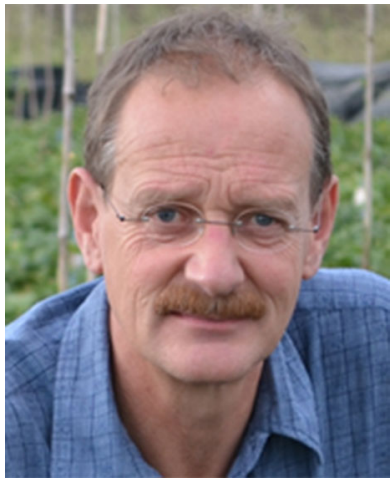

Ken Giller is Professor of Plant Production Systems (PPS) at Wageningen University. He joined Wageningen University as Chair of PPS in 2001 after holding professorships at Wye College, University of London, and the University of Zimbabwe. Ken's research has focused on smallholder farming systems in sub-Saharan Africa, and in particular problems of soil fertility and the role of nitrogen fixation in tropical legumes, with emphasis on the temporal and spatial dynamics of resources within crop/livestock farming systems and their interactions. He leads a number of initiatives such as N2Africa - Putting Nitrogen Fixation to Work for Smallholder Farmers in Africa. Ken is member of the Unilever Sustainable Sourcing Advisory Board. He is co-chair of the Thematic Network 7 on Sustainable Agriculture and Food Systems of the Sustainable Development Solutions Network (SDSN) of the United Nations.

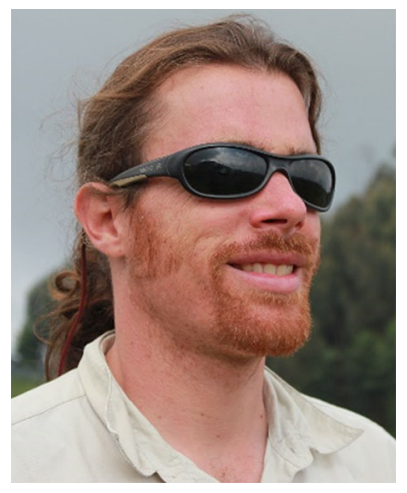

Frédéric Baudron is a principal scientist working for the International Maize and Wheat Improvement Centre (CIMMYT) based in Harare, Zimbabwe. Trained as a tropical agronomist, he specialized as a livestock scientist and started his carrier working for various development programs targeting the interface between people (mainly farmers) and wildlife. He then conducted his $\mathrm{PhD}$ on plant production systems. His research interests include farming system research, sustainable intensification, impact of agriculture on biodiversity, appropriate mechanization and participatory innovation development. He is involved in a number of research projects in Ethiopia, Kenya, Rwanda, Tanzania, Zambia and Zimbabwe. 